\title{
Policy Formulations of the Fisheries Criminal Act: An Investigation of the Authority of the Criminal Justice System in Indonesia
}

\author{
Deassy J. A. Hehanussa (Corresponding Author) \\ Doctoral students of Law, Faculty of Law University of Brawijaya \\ Malang Indonesia
}

Koesno Adi

Faculty of Law, University of Brawijaya

Malang Indonesia

Masruchin Ruba'i

Faculty of Law, University of Brawijaya

Malang Indonesia

Pridja Djatmika

Faculty of Law, University of Brawijaya

Malang Indonesia

Received: September 21, 2013 Accepted: March 5, $2014 \quad$ Published: March 20, 2014

doi:10.5296/ijssr.v2i1.5329 URL: http://dx.doi.org/10.5296/ijssr.v2i1.5329

\begin{abstract}
Law enforcement implementation of fisheries criminal act especially for investigation based on Article 73 (1) of Law No. 45 of 2009 is executed by Fishery Civil Servant Investigator (PPNS), Investigator of Indonesian Navy officer and/or Investigator of Indonesian National Police. This investigation authority is called as attribution authority meaning that the
\end{abstract}


authority is granted by the order of law. This regulation grants the same authority to these three institutions to investigate and submit their investigation report to public prosecutor without any cohesive system in its implementation. If it is linked to Law No. 8 of 1981 as an illustration of criminal justice system of Indonesia which is referred as the basis of common and specific criminal law enforcement, it emerges juridical weakness as a consequence of regulation inconsistency including conflict of norm between Criminal Procedure Code (KUHAP) and Fisheries Act. This inconsistency emerges conflict of authority among those investigators and emerges law indeterminacy. Hence, reformulate investigation authority of fisheries criminal act needs to be conducted along with paying attention on waters territory of Indonesia upon Law No. 6 of 1996 about Waters Territory of Indonesia despite law enforcement mechanism which had to be enforced corporately. This study result concludes that inconsistency of investigation authority formulation in fisheries criminal act in criminal justice system not only emerges fuzziness of norm but also conflict of norm between Law No. 8 of 1981 about Criminal Procedure Code and Law No. 45 of 2009. This emerges because there is an overlapping of investigation authority among 3 institutions, i.e., Fishery Civil Servant, Indonesian Navy and the Police. Formation team of Indonesian Maritime Security Coordinating Board (Bakorkamla) only has an authority as coordinating function. Hence, to maximize the law enforcement in the ocean, function of Indonesian Maritime Security Coordinating Board should be improved as a coordinator of law enforcement in ocean territory of Indonesia.

Keywords: investigation authority, fisheries criminal act, criminal justice system of Indonesia

\section{Introduction}

As an archipelagic island country, Indonesia has a larger ocean territory area than its land territory, that is 9: 1 (Etty, 1991), and geographically it is lying in a strategic position between two continents (Asia and Australia) and two oceans (Pacific and Indian) (Atja, 1993). As the biggest archipelagic island country in the world, Indonesia has about 18,306 wide and narrow island with approximate shoreline by $95,181 \mathrm{~km}$ and ocean territory area by 5.8 million $\mathrm{km}^{2}$ (including Indonesian Exclusive Economic Zone) (Alex Retraubun, 2007).

Essentially, natural resources development and utilization including fisheries as national asset is a mandate of paragraph IV of the Preamble to the 1945 Constitution of the Republic of Indonesia as details in Article 33 paragraph 3 to the 1945 Constitution of the Republic of the Indonesia by stating that: "The land, the waters and the natural riches contained therein shall be controlled by the State and exploited to the greatest benefit of the people". Abundant of fisheries natural riches and geographical strategic position of Indonesian waters as well as high intensity of economic wheel enable an emergence of various felonious criminal act in Indonesian jurisdiction, such as illegal fishing.

Practically, investigation upon these fisheries criminal acts are executed by 3 (three) institutions in accordance with the Law of Article 73 No. 45 of 2009 about Fisheries, that is Department of Fisheries and Marine, Indonesian Navy and Indonesian National Police. It is 
interesting that the law gives the same authority to those three institutions in fisheries law enforcement without any cohesive system in its implementation.

This disintegration wreaks conflict of authorities during law enforcement in fisheries affairs. It is said as conflict of authority because these three institutions have the same authority in handling the same authority case, that is doing the investigation, filling of BAP and submitting the case files to public prosecutor without any cohesive system in its implementation. This fact effects on fisheries law enforcement process because of an absence of cohesive system.

Starting from the existing phenomena either social, economy or law occurring in fisheries law enforcement, it triggers some problems, first from philosophical side that the State has the duty of giving welfare to its people along with protecting natural resources including fishery. One of the conducted efforts in law enforcement process has an end purpose to gain legal certainty. Second, theoretically, emerged problem which is the occurrence of criminal judicature system theory shift, from which the investigation norm of fisheries criminal act has the same authority to investigate and submit its investigation report to public prosecutor, has a potential ability to break the arranged criminal judicature system as referred to Law No. 8 of 1981. This law acknowledges that police has a duty of being the main investigator, coordinator and also the supervisor of a civil servant investigator. Third, juridical problem is pointed out by the conflict of norm between Article 73 of Law No. 45 of 2009 about fisheries and Article 7 (2) of Law No. 8 of 1981 about Criminal Procedures. It states that certain civil servant investigator who is granted a special authority by the law in his performance of duties lies under coordination and supervision of Indonesian National Police authorities. On the other hand, article 73B (1) of Law No. 45 of 2009 states that investigator as mentioned in Article 73 informs the beginning of investigation to public prosecutor maximum 7 (seven) days after finding out the criminal act in fisheries field. In fact, there is a shift in article 73 of Law No. 45 of 2009 saying that Fishery Civil Servant Investigator, Indonesian Navy and Police has an equal position and has an authority to submit their investigation report to public prosecutor. This case is in contradiction to criminal justice system by proposing coordination among the existing sub systems including investigation. Fourth, sociological problem is pointed out as the consequence of regulation inconsistency for Law No. 45 of 2009 effecting on law enforcement which does not run well and affects on fisheries criminal act settlement in fisheries management territory of Indonesia.

Based on mentioned rationale above, the following will inspect formulation policy of fisheries criminal act investigation authority in criminal justice system of Indonesia for the future. This study is conducted for the future of criminal judicature of Indonesia. This study is conducted by closely watching laws and regulations which had applied and is applicable (ius constituendum) then trying to formulate regulation of fisheries criminal act investigation authority for the future (ius constituendum).

\section{Research Methodology}

This study concerns on study toward laws norm which can be grouped into kinds of normative laws studies (Mukti \& Yulianto, 2010). In accordance with characteristic of 
normative study, applied approach in this study is a statute approach. Statute approach is applied to understand consistency and suitability between one law and the others or between law and the Constitution (Peter, 2005). Besides, this study also applies concept approach to analyze developing view and doctrine in jurisprudence by expecting to discover explanation of law and concept of law which is relevant to investigated issues. Law comparison approach is also applied to find the similarities and the differences regulation of fisheries criminal act investigation authority in criminal justice system of Indonesia, by comparing regulation of investigation authority owned by other country which is going to be used as comparison. According to Sunaryati Hartono, this comparison covers three main elements, they are legal structure, legal subtance and legal culture (Soerjono, 1989). Comparison can be conducted toward one of the elements or all of the elements.

As a study of normative law, applied main material in this study is law materials including primary law material, secondary law material and tertiary law material. Applied primary law material covers the 1945 of Constitution of the Republic of the Indonesia, Law No. 8 of 1981 about Criminal Procedure Code, Law No. 31 of 2004 and Law No. 45 of 2009 about fisheries and the other relevant laws and regulations. Applied secondary law materials are Bills of Criminal Procedure Code, text books, law journal and the other law materials which are relevant to fisheries criminal act investigation authority in criminal justice system. In addition, tertiary law material including legal dictionary and dictionary of the Indonesian language are used as the supporting material which are utilized to do terminologies grammatical interpretation (Soerjono \& Sri, 2010).

\section{Results and Discussion}

\subsection{Law Enforcement Problems of Fisheries Criminal Act}

Marine resources potential as well as fisheries owned by Indonesia as archipelagic island country is very rich indeed. In this context, it is not surprised if the vast expanse of the sea territory makes the government unable to handle monitoring and to take action against those violators who commit illegal fisheries acts.

Result of licensing inventory at Department of Fisheries and Marine of Indonesia, from the estimated of s7,000 given licenses of fishing vessels, the 70\% are given to foreign fishing vessels. Hence, an estimate of the amount of losses can reach may be as much as 16.6 trillion rupiahs per year. Forms of which include lost fees, skilled labor dues that is loss in forms of fee lost, labor skill dues, haul dues and indirect loss because of refined fuel oil subsidy (Ahmad Fauzi, 2005).

Initial study carried out by Fauzi shows that there are some propelling factors to the occurrence of illegal utilization (used and abused) toward fishery resources in Indonesian waters territory (Ahmad, 2005), that is:

a. There is an inanity of fishing fleet in some regions in Indonesia, such as Arafura Sea, South China Sea, Celebes Sea and Pacific Ocean;

b. Law enforcement does not run well as it should be; 
c. Investment which does not run well as consequence of prolonged economic and politic crisis emerges uncertainty condition in business;

d. Geographical condition of Indonesian waters enables undetectable illegal fishing (hit and run).

By these factors, it cannot be denied that illegal fishing phenomena is a part of naval development problems in Indonesia which is later on stated in Presidential Regulation No. 7 of 2005 about National Medium-term Development Plans of 2004 - 2009, asserting that illegal fishing, which are conducted either by the domestic fishing vessel or unlicensed foreign fishing vessel in territorial waters or Indonesian Exclusive Economic Zone (IEEZ), causes lost of fisheries resource at around 1-1.5 million ton per year by state lost value around US\$ 2 billion.

Some important issues in fisheries development include excessive fishing phenomenon, illegal fishing and the other illegal fishing which are not only causing state lost but also threatening fisherman's interest.

By paying attention to those issues, law enforcement in fisheries field turns to be urgent and strategic matter in supporting controlled fisheries development and appropriate fisheries management principles in order to gain continuous fisheries development. Hence, presence of law certainty is an absolute condition in criminal act handling in fisheries affairs including investigation, prosecution and inspection of court.

Related to investigation specifically, article 72 asserts that "investigation of criminal act in fisheries affairs is conducted based on applicable law of procedure unless it is determined differently in this law".

a. Article 73 (1) of Law No. 45 of 2009 formulates that

b. Investigation of criminal law in fishery field in fisheries management territory of the Republic of Indonesia is executed by Fishery Civil Servant Investigator, Investigator of Indonesian Navy officer and/or Investigator of Indonesian National Police.

c. In addition to Indonesian Navy, Fishery Civil Servant Investigator have the power to investigate criminal act in fishery field which are committed in IEEZ.

d. Investigation on criminal act in fishery field occurs in fish port which is mainly executed by Fishery Civil Servant Investigator.

e. Investigator as intended in subsection (1) may do coordination in handling investigation of criminal act in fishery field.

f. To do this coordination of handling criminal act in fishery field as intended in subsection (4), Minister forms coordination forum.

In explanation of article 73 (2), it is asserted that "in addition to gain implementation fluency of investigator's duty, coordination is intended to expedite communication and to exchange data, information and other necessary matters in order to gain effectiveness and efficiency of handling process and/or completion of fishery criminal act". 
In fact, handling coordination forum of fishery criminal act has been formed in central board, and so does as expected in some regions whether in province and regency/city. However, what is still in question is what kind of authority of this coordination forum in law enforcement is, because if one of the three law enforcer institutions do not implement its function, there will be no sanction. Ironically, those three institutions do their duty individually.

If it is returned to Law No. 8 of 1981 about Criminal Procedure Code, it is clearly stated in Article 7 (2) that, "Investigator as intended in article 6(1) in b point has authority correspond to the law as its each legal basis, then for his performance of duties lies under coordination and supervision of the investigator in article 6 (1) in a point". It shows that Criminal Procedure Code as procedural design of Indonesian criminal judicature system implementation in handling of certain criminal act case has explicitly appointed investigator of Indonesian National Police's duty concerning Civil Servant Investigator who executes investigation duty correspond to special authority as given by law with its individual legal basis.

Associated with the implementation of criminal judicature system, meaning of "integrated system" in fishery's law enforcement, is directed to a system unity. It means that if one of the fishery's law enforcer institution arrests illegal fishing vessel, at that moment, the criminal act is detected by the other fishery's law enforcer institutions (that is detected by the three institutions of criminal act investigator in fishery field, and even detected by institution of Attorney and Fishery's Court). Hence, the presence of supervisory system is an urgent in fishery's law enforcement especially for supervision toward those three fishery's law enforcer institutions lying under the three sectoral institutions.

What has been summoned has a reason because from the law enforcement perspective, it is admitted that law enforcement is an effort to enforce the norm as well as values behind this norm (Muladi, 1997). It contains an implication that the purpose of law enforcement is not only to reach law certainty, but also the justice. Hence, the purpose of norm enforcement is law certainty, while the purpose of value enforcement is the justice.

In the framework of criminal justice system, coordination is an important component to realize cohesiveness. Law No. 8 of 1981 settles Police as the coordinator and supervisor of Civil Servant Investigator, but explanation of Article 73B formulates investigation that is executed by Fishery Civil Servant Investigator has coordinative characteristic with Investigator of Indonesian Navy officer in order to run the process efficiently and effectively according to Joint Standard Operating Procedures. Ambiguity of norm regulation affects on law certainty that belongs to the end purpose of law increasingly cannot be realized.

On the other side, fishery criminal act can be committed in ocean territory of Indonesian sovereignty such as Indonesian sea territory, islands' waters and inland waters and also in EEZ and mare liberum. As an archipelagic island country, according to Law No. 6 of 1996, Indonesia has law sovereignty upon Indonesian waters territory as well as criminal law implementation. It means that authority of Indonesia as coastal country in ocean territory as the mentioned division are limited. This case also correlates to the law enforcement of fishery criminal act. Although investigation authority of EEZ is executed by Indonesian Navy, it still 
depicts conflict of authority during investigation practical work because the Law does not clearly and explicitly arrange it, thus it emerges different interpretation.

This problem occurs in the process of law enforcement especially in investigation process as the judgment basis to create investigation authority formulation of fishery criminal act that directs to a cohesive criminal justice system unity.

\subsection{Investigation Authority Formulation of Fishery Criminal Act}

According to Lobby Loqman, by closely watching the emergence of new developing criminal act in society and anticipation necessary in the regulation of national criminal law system, specific criminal law may be conducted because:

a. There is a criminalization process of certain deed in society. This criminalization progress in society emerges view shift and society evaluation upon certain deed. If a deed is considered as something bad, it turns to be a "bad" deed although this deed has not been settled in any criminal laws and regulations.

b. Then, the existing law is considered as inappropriate to norm shift and technology development in society, whereas law changing process wastes time too much.

c. There is an importunate condition from which a special regulation is needed to handle the case immediately.

d. There is a special deed, from which if an existing process is applied, there will be a difficulty on showing the evidence (Loebby, 1993).

If a special criminal law has settled certain field in life of society and has been fixed as positive law, provision of that special criminal law is called as "Special Criminal Law", meaning that it is not only has special meaning for itself (legislation of Dutch called it as"afzonderlijke wetten"), but also has special aim, meaning that there are a lot of deviations of common criminal, specially for those stipulation in Criminal Code (KUHP) It also has characteristic of temporary meaning that it was created to face a certain situation or condition of society. If that condition turns back to normal, the formulations are erased and turned to the existing common law (Andi, 1986).

Actually the formation of Special Criminal Law is considered as a criminal politic, meaning that it is an effort of society by relating various governments' element to rationally face the crimes. Essentially, during this criminal politic or specifically during criminal law politic, condition are directed to renewal of criminal law. It means an effort to do reorientation or reformation of criminal law to make it appropriate with central values of socio-politic, socio-philosophical and socio-cultural of Indonesian people for being the basis of social policy, criminal policy and law enforcement policy in Indonesia (Barda, 2009). In other words, essentially, the renewal of criminal law should be taken by policy-oriented approach and value-oriented approach (Barda, 2009).

Problem of law enforcement and security raising effort in Indonesian ocean still need a great attention. This ocean territory consists of Indonesian waters and EEZ with 6 million $\mathrm{km} 2$ in 
width by considering that it is 3 times larger than its land territory. Ability-raising of law enforcement and security cover a tight cooperation among all activities in land, water and sky. Otherwise, efforts to raise ability in monitoring, controlling, surveillance and also inquisition, investigation and judicial proceeding should be arranged as well as possible.

In terms of realizing integrated criminal justice system through model design in Law No. 8 of 1981, it leaves other problems where a Police is the main investigator as well as the coordinator and supervisor of Civil Servant Investigator. It means that process of investigation executed by Civil Servant Investigator should be coordinated and supervised by the Police. As time goes by, the development of new criminal act where the formulation of norm and criminal procedure are arranged, it is seen an occurrence of orientation shift by giving the same authority to Civil Servant Investigator or the other investigators such as Indonesian Navy. This orientation shift does not belong to criminal justice sub system without any coordination with the Police as the main investigator. This paradigm is also seen by the emergence of investigation regulation in Bills of Criminal Procedure Code that does not give signal of coordination between the police and the other investigators. It is mentioned in Article 6 and 8 of Bills of Criminal Procedure Code by stating:

Article 6

(1) Investigator is:

(2) Indonesian National Police official

(3) civil servant official who is specially appointed according to certain Law and granted an authority to do investigation:

(4) official of an institution that is specially appointed according to certain law and granted an authority to do investigation

Article 8

(1) In executing the investigation, the Investigator coordinates with public prosecutor.

(2) Investigator creates a report about the implementation of needed handling effort in the completion of case as intended in Article 109 corresponding to the regulation in this law.

(3) Investigator submits complete case file to the Public Prosecutor.

If the Bills of Criminal Procedure Code from the government is observed, it is seen that there is shift of investigation sub system paradigm as followed by Law No. 8 of 1981 where the Police as the main investigator of criminal act and also being the coordinator and supervisor of Civil Servant Investigator by giving similar position to the Police, Civil Servant Official as well as official of an institution who are specially appointed as the investigator. As the consequence of this similar authority, coordination is only conducted by the help of public prosecutor. Hence, in order to conduct unification and codification of Criminal Procedure Code, it is advisable for formulation policy that criminalize various kinds of new crime out of 
criminal code, do not arrange its own criminal procedure, but it should still subject to Criminal Procedure Code.

According to Hasyim Djalal, if it is related to uncertainty of coordination and authority division, responsibility among competent authority including supervision will emerge confusion, overlapping jurisdiction, and even conflicting jurisdiction (Hasyim, 2009).

The only existing coordination is conducted by setting up Indonesian Maritime Security Coordinating Board under decision among 5 officials, they are Minister of Defense, Minister of Transportation, Minister of Finance, Minister of Justice, Attorney General, Staff Head of Indonesian Navy and Head of Indonesian National Police. Each of them may appoint one of their important sub-official to execute daily duties of Indonesian Maritime Security Coordinating Board. The Indonesian Maritime Security Coordinating Board has the duty of coordinating security operations in the Indonesian ocean and solving emerging problems as the consequence of a violation or crime therein. This execution is handed over to Marine Security Task Force lead by Indonesian Navy officer who had been appointed by Commander of Defense Territorial Command.

Based on conducted observation and analysis, it is needed to relearn position of Indonesian Maritime Security Coordinating Board. Its authority can be increased to Maritime Security Entity. Besides, produced product of law which is only based on joint decree should be increased by Presidential Decree or Government Regulation in order to increase its authority from coordination to supervision institution.

\section{Conclusion}

Inconsistency of investigation authority formulation in fisheries criminal act of criminal justice system emerges fuzziness of norm as well as conflict of norm between Law No. 8 of 1981 about Criminal Procedure Code and Law No. 45 of 2009 because there is an overlapping of investigation authority among 3 institutions, they are Fishery Civil Servant, Indonesian Navy and the Police. Actually, there has been a special institution which solves investigation in ocean territory including fishery and the other illegal activities committed in the ocean, that is Indonesian Maritime Security Coordinating Board. Hence, to optimize the law enforcement in the sea, the function of Indonesian Maritime Security Coordinating Board should be improved as the coordinator of law enforcement in the ocean.

As a part of international communities, Indonesia is known as a coastal country having different law enforcement sovereignty whether in ocean territory in Indonesian sovereignty, EZZ or mare liberum (the Free Sea) based on the 1982 of Admiralty Law Convention. Fishery criminal act can be committed not only in Indonesian sea territory, but also in EEZ and mare liberum territory. Hence, law enforcement arranged in Law No. 45 of 2009 needs to be explicitly arranged by paying attention on zone division as stated in the 1982 of Admiralty Law Convention. In fact, regulation implementation of fishery criminal act investigation authority by giving authority to each institution to issue policy regulation still emerges different interpretation. This matter can ruin criminal justice system affecting on unrealized law certainty. 


\section{References}

Abdusalam. (1997). Penegakan Hukum Dilapangan Oleh POLRI. Dinas Hukum POLRI, Jakarta.

Agoes, E. R. (1991). Konvensi Hukum Laut 1982 dan Masalah Pengaturan Hak Lintas Kapal Asing. CV Abardin. Bandung.

Ahmad, Fauzi. (2005). Kebijakan Perikanan dan Kelautan, Isu, Sintesis, dan Gagasan. Penerbit PT Gramedia Pustaka Utama, Jakarta.

Atja, Misbach. M. (1993). Status Hukum Perairan Kepulauan Indonesia dan Hak Lintas Kapal Asing. Bandung: Alumni.

Aziz, Syamsudin. (2011). Tindak Pidana Khusus. Jakarta: Sinar Grafika.

Barda, Nawawi. Arief. (2009). "Reformasi Sistem Peradilan (Sistem Penegakan Hukum)" Artikel.

Dhiana, Puspitawati. (2008). The Concept of an Archipelagic State and Its Implementation in Indonesia. Dissertation, University of Queensland.

Dina, Sunyowati. (n.d.). ZEE dan Perikanan, Bahan Kuliah Hukum Laut Internasional, Fakultas Hukum, Universitas Airlangga.

Hamzah, A. (1986). Sistem Pidana dan Pemidanaan Indonesia dari Retribusi ke Reformasi. Pradnya Paramita.

Hasyim, D. (2009). Mengelola Potensi Laut Indonesia, Jurnal Luar negeri, Badan Pengkajian dan Pengembangan Kebijakan Departemen Luar Negeri, September-Desember 2009.

Loqman, L. (1993). Delik Politik di Indonesia. IND-HILL.

Mochtar Kusumaatmadja dan Etty R. Agoes. (2012). Pengantar Hukum International, Bandung: Pusat Studi Wawasan Nusantara dan Pembangunan Bekerjasama dengan PT Alumni, Bandung,

Mukti Fajar dan Yulianto Achmad. (2010). Dualisme Penelitian Hukum Normatif dan Empiris, Yogyakarta: Pustaka Pelajar.

Peter Mahmud Marzuki. (2005). Penelitian Hukum, Jakarta: Prenada Media.

Rancangan Undang-Undang Republik Indonesia Tentang Hukum Acara Pidana. (2010).

Republik Indonesia. Undang-Undang Dasar Negara Republik Indonesia Tahun. (1945).

Republik Indonesia. Undang-Undang Tentang Kitab Undang-Undang Hukum Acara Pidana. UU Nomor 8 Tahun. (1981). Lembaran Negara Republik Indonesia Tahun 1981 Nomor 76. Tambahan Lembaran Negara Republik Indonesia Nomor 3209. 


\section{Macrothink}

International Journal of Social Science Research

ISSN 2327-5510 2014, Vol. 2, No. 1

Republik Indonesia. Undang-Undang Tentang Perairan Indonesia. UU No. 6 Tahun. (1996). Lembaran Negara Republik Indonesia Tahun 1996 Nomor 73. Tambahan Lembaran Negara Republik Indonesia Nomor 3647.

Republik Indonesia. Undang-Undang Tentang Perikanan. UU Nomor 31 Tahun. (2004). Lembaran Negara Republik Indonesia Tahun 2004 Nomor 118. Tambahan Lembaran Negara Republik Indonesia Nomor 4433 jo UU Nomor 45 Tahun 2009. Lembaran Negara Republik Indonesia Tahun 2009 Nomor 154. Tambahan Lembaran Negara Republik Indonesia Nomor 5073 .

Retraubun Alex. S. W. (2007). Isu Pulau-Pulau Kecil Sebagai Dasar Pijak Kebijakan Pembangunan Daerah Kepulauan. Pidato Pengukuhan Guru Besar Universitas Pattimura, 4 Agustus 2007.

Sefriani. (2010). Hukum International Suatu Pengantar. Jakarta: PT RajaGrafindo Persada, 2010 .

Soekanto, S. (1983). Faktor-Faktor yang Mempengaruhi Penegakan Hukum. Rajawali.

Soerjono Soekanto dan Sri Mamudji. (2010). Penelitian Hukum Normatif, Suatu Tinjauan Singkat, Jakarta: PT RajaGrafindo Persada.

Soerjono, Soekanto. (1989). Perbandingan Hukum. Bandung: Citra Aditya Bakti

Sudarto. (1986). Kapita Selekta Hukum Pidana. Bandung: Alumni.

Victor PH Nikijuluw. (2008). Blue Water Crime, Cidesindo, Jakarta.

\section{Copyright Disclaimer}

Copyright reserved by the author(s).

This article is an open-access article distributed under the terms and conditions of the Creative Commons Attribution license (http://creativecommons.org/licenses/by/3.0/). 